19 Revue d'histoire du XIXe siècle

Société d'histoire de la révolution de 1848 et des

révolutions du XIXe siècle

$10 \mid 1994$

Le silence au XIXe siècle

\title{
Relecture de la Restauration
}

Francis Démier

URL: http://journals.openedition.org/rh19/77

DOI: $10.4000 /$ rh19.77

ISSN: 1777-5329

Publisher

La Société de 1848

Printed version

Date of publication: 1 June 1994

ISSN: 1265-1354

Electronic reference

Francis Démier, "Relecture de la Restauration », Revue d'histoire du XIXe siècle [Online], 10 | 1994,

Online since 09 September 2008, connection on 19 April 2019. URL : http://journals.openedition.org/ rh19/77 ; DOl : 10.4000/rh19.77

This text was automatically generated on 19 April 2019

Tous droits réservés 


\title{
Relecture de la Restauration
}

\author{
Francis Démier
}

\section{ABSTRACTS}

Reading over the Restauration The archives of the great economic institutions allow us to think that from as early as 1814, the restored monarchy fully asserted the idea of nation. Thanks to the economic stake of modernisation, the nation could find its true identity in a peaceful Europe. The influence of Jean-Baptiste Say remains limited to Paris. The economists of the nation are liberals attached to the market such as Chaptal, Dutens, Tollenare. They elaborated a synthesis of Colbert and Smith: the market must be defined in the political frame of the nation which itself definies a new conception of economic geography in France. Consequently, the aim would be to allow greatest economic liberty and the greatest protection of production inside national boundaries. From the 1820 s, protectionism, of which certain main lines were defined by the manufacturers, clearly undertakes a new mission: to revalue agricultural prices and land rent. In this way, the 1814 project of an economy-nation articulated around the Manufactury, which should have given back to France its status of political power alongside England, diverts itself towards a singular drift.

Les archives des grandes institutions économiques donnent le sentiment que dès 1814, l'idée de nation, pour les équipes de la monarchie restaurée, peut véritablement s'affirmer. Grâce au grand enjeu économique de la modernisation, la nation pourra trouver sa véritable identité dans l'Europe de la paix. Le rayonnement de Jean-Baptiste Say reste borné à des cercles parisiens. Les économistes de la nation, ce sont des libéraux attachés au marché comme Chaptal, Dutens, Ganith, Tollenare. Ils pratiquent une synthèse à mi-distance de Colbert et de Smith : le marché doit se définir dans le cadre politique de la nation qui définit une nouvelle conception de la géographie économique de la France. Désormais, il s'agit de favoriser la plus grande liberté économique dans l'espace national et la plus grande protection de l'appareil productif de la 
France aux frontières de la nation. À partir des années 1820 , le protectionnisme, dont les contours ont été défini en partie par les manufacturiers, se voit attribuer très clairement une nouvelle mission : revaloriser les prix agricoles et la rente foncière. De la sorte, le projet de 1814 d'une économie-nation, articulée autour de la Manufacture qui devait redonner à la France, face à l'Angleterre, le statut d'une grande puissance connaît une singulière dérive.

INDEX

Mots-clés: Histoire économique, Histoire intellectuelle, Restauration 